\title{
Evaluation of the Effects \\ of Buccal-Palatal Bone Width \\ on the Incidence and Height \\ of the Interproximal Papilla Between Adjacent Implants in Esthetic Areas
}

Sergio Siqueira Jr., * Suzana P. Pimentel, ${ }^{\dagger}$ Renato V. Alves, ${ }^{\ddagger}$ Wilson Sendyk,$\S$ and Patricia R. Cury ${ }^{\|}$

Background: The presence of interproximal papilla depends on the distance between the contact point to the bone crest, as well as the mesio-distal distance between implants or between implants and teeth. The aim of this study is to evaluate the effects of buccal-palatal bone width on the presence of the interproximal papilla between adjacent implants in esthetic areas of the mouth.

Methods: The presence or absence of the gingival papilla, distance from the base of the interproximal contact to the tip of the gingival papilla (black space), distance from the base of the interproximal contact to the alveolar crest (vertical distance), alveolar bone width (bone width) between adjacent implants as well as the spacing between the implants (horizontal distance), and soft-tissue biotype were assessed in 29 interimplant areas in the upper incisor, canine, and premolar regions of 18 patients.

Results: The papilla was always present when vertical distance was $\leq 5 \mathrm{~mm}(P \leq 0.04)$ and frequently present when the horizontal distance was $\geq 4 \mathrm{~mm}(P=0.04)$. The black space was smaller when the vertical distance was $\leq 5 \mathrm{~mm}(P \leq 0.04)$ and when the horizontal distance was $\geq 4 \mathrm{~mm}(P=0.76)$. Bone width and soft-tissue biotype did not influence the incidence of gingival papilla $(P \geq 0.41)$ and black space $(P \geq 0.15)$.

Conclusion: Within the limits of this study, it can be concluded that bone width and tissue biotype do not have an effect on the incidence and height of papilla between adjacent implants in esthetic areas, and the incidence was greater when vertical distance was $\leq 5 \mathrm{~mm}$ or when horizontal distance was $\geq 4 \mathrm{~mm}$. J Periodontol 2013;84:170-175.

\section{KEY WORDS}

Alveolar bone loss; dental implants; dental papilla; dental prosthesis, esthetics, dental.

\footnotetext{
* Department of Implantology, National Service for Commercial Education, São Paulo, Brazil.

$†$ Department of Periodontics, School of Dentistry, Paulista University, São Paulo, Brazil.

† Department of Periodontics, School of Dentistry, State University of Pernambuco, Recife, Brazil.

$\S$ Department of Periodontics and Implantology, School of Dentistry, University of Santo Amaro, São Paulo, Brazil

|| Department of Periodontics, School of Dentistry, Federal University of Bahia, Bahia Salvador, Brazil.
}

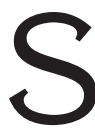
everal factors must be considered for a good esthetic outcome in patients rehabilitated with dental implants. These include the position of the implants in the arch, the relationship with adjacent teeth or implants, and the presence and anatomy of the remaining bone tissue. ${ }^{1}$ Any deviation from the optimal position may create difficulties, such as the presence of interproximal papilla, in the final prosthetic restoration and jeopardize the esthetic outcome.

The factors affecting the presence or absence of the gingival papilla between implants are not completely understood. Previous research has shown that the presence of gingival papilla depends on the distance from the base of the interproximal contact to the alveolar crest and the spacing between implants or between implants and teeth. Specifically, when the spacing is $\leq 3 \mathrm{~mm},{ }^{2}$ the amount of crestal bone loss is generally greater, leading to a lower incidence of the occurrence of gingival papillae..$^{3,4}$ Furthermore, Choquet et al. ${ }^{3}$ reported that the gingival papilla fills the entire interproximal space in $80 \%$ of the cases when the distance from the base of the interproximal contact to the alveolar crest is $3 \mathrm{~mm}$. In this context, the ideal distance from the base of the

doi: 10.1902/jop.2012.110638 
interproximal contact to the alveolar crest and the ideal spacing between adjacent implants was shown to be 3 and 3 to $4 \mathrm{~mm}$, respectively. ${ }^{4}$ When the spacing is $\leq 2.5 \mathrm{~mm}$, gingival papilla is generally absent, independent of the bone height; however, the presence of gingival papilla depends on both the bone height and spacing between adjacent implants when the latter is $\geq 3.0 \mathrm{~mm} .{ }^{4}$ Moreover, crestal bone loss in interimplant areas influences both the bone height and the bone width, resulting in changes in the soft tissue and affecting the height of the papilla. ${ }^{5,6}$

To the best of our knowledge, three-dimensional evaluation of the interproximal area between adjacent implants, including mesio-distal, apico-coronal, and buccal-palatal distances, has not been performed. Therefore, we aimed to evaluate the effects of buccal-palatal bone width on the presence and height of the gingival papilla between adjacent implants in esthetic areas.

\section{MATERIALS AND METHODS}

This study was approved by the Institutional Committee for Ethics of the School of Dentistry of the University of Santo Amaro, São Paulo, Brazil, and written informed consent was obtained from all participants.

\section{Case Selection}

We considered 29 interimplant areas in 18 patients (10 males and eight females; aged 19 to 72 years) who were treated at the dental clinic of either the University of Santo Amaro or the Brazilian Association of Teaching Dentistry, São Paulo, Brazil, from January to December 2005 and provided written informed consent. Only esthetic areas (upper incisor, canine, and premolar regions) treated using external hexagon implants with standard platforms were assessed. The surgical and prosthetic protocols recommended by the manufacturers were followed, and the patients retained the implant-supported fixed prostheses for 6 months to 5 years. Patients with a history of bone grafting or clinical signs of gingival inflammation, mucositis, peri-implantitis, or periodontitis were not included.

\section{Clinical Evaluation}

A single trained examiner (SS) evaluated the following parameters (Fig. 1): 1) presence or absence of gingival papillae; 2) distance from the base of the interproximal contact to the tip of the gingival papilla or black space; 3 ) vertical distance from the base of the interproximal contact point to the alveolar bone crest; 4) mesio-distal distance between the implants; and 5) vestibular palatal alveolar bone width.

Visual evaluation of the presence or absence of the papilla was performed perpendicularly to the buc- cal surface of the restoration crown before probing. The classification index ${ }^{7}$ is defined as: score 0 , no papilla present; score 1 , less than half of the papilla present; score 2, at least half of the papilla present but does not extend to the contact point between crowns; and score 3, papilla fills the entire proximal space. Score 4 was not used, because no hyperplastic papillae were observed. For the statistical analyses, the papilla was considered absent when assessed with a score 0 or 1 and present when categorized as score 2 or 3.

To measure the vertical distance, the patients were anesthetized, and a rounded-tip steel endodontic spreader with a rubber stop was inserted vertically into the gingiva on the buccal aspect of the interproximal contact until the alveolar crest was reached. This distance was measured using a digital caliper. "

The horizontal distance between the implant platforms was measured with a digital caliper\# ${ }^{\#}$ on stone models made during the prosthetic phase.

The black space was measured by using a periodontal probe, ${ }^{* *}$ and the measurements were rounded to the nearest millimeter. The bone width was measured by using calipers ${ }^{\dagger \dagger}$ inserted into the buccal and palatal mucosa $1 \mathrm{~mm}$ apical to the alveolar crest. One millimeter was added to the vertical distance to localize this position. In this same position, the soft-tissue thickness was measured. A rounded-tip steel endodontic spreader with a rubber stop was inserted horizontally into the gingiva until the alveolar crest was reached. This distance was measured using a digital caliper. ${ }^{\neq} \neq$Interimplant areas with soft-tissue thickness of $\geq 2.5 \mathrm{~mm}$ were considered thick biotype, and areas with a soft-tissue thickness was $<2.5 \mathrm{~mm}$ were considered thin biotype. ${ }^{8}$

\section{Statistical Analyses}

Differences between the means were compared by Student $t$ test or Tukey test when the variables showed a normal distribution ( $P>0.05$ for Levene test) or by the Mann-Whitney $U$ test when they did not show a normal distribution. Analysis of variance and Tukey test were used to compare the black space among different bone widths ( $\leq 2$ and $>2, \leq 3$ and $>3$ $\mathrm{mm})$. Student $t$ test was also used to compare the vertical $(\leq 5$ and $>5 \mathrm{~mm}$ ) and horizontal ( $\leq 4$ and $>4 \mathrm{~mm}$ ) distances of the patients with and without papillae. Pearson correlation test was used to study the relationships between black space and vertical and horizontal distances and bone width. The categorical variables were analyzed using the $\chi^{2}$ or

\footnotetext{
I Electronic digital caliper, 150 mm, Lee Tools, Dongguan, China. \# Electronic digital caliper, $150 \mathrm{~mm}$, Lee Tools.

* * PCP-15, Hu-Friedy, Chicago, IL.

$\dagger \dagger$ Weiss modified Castroviejo calipers, 7 inches, Dental Surgical, Sialkot, Pakistan.
}

キキ Electronic digital caliper, $150 \mathrm{~mm}$, Lee Tools. 

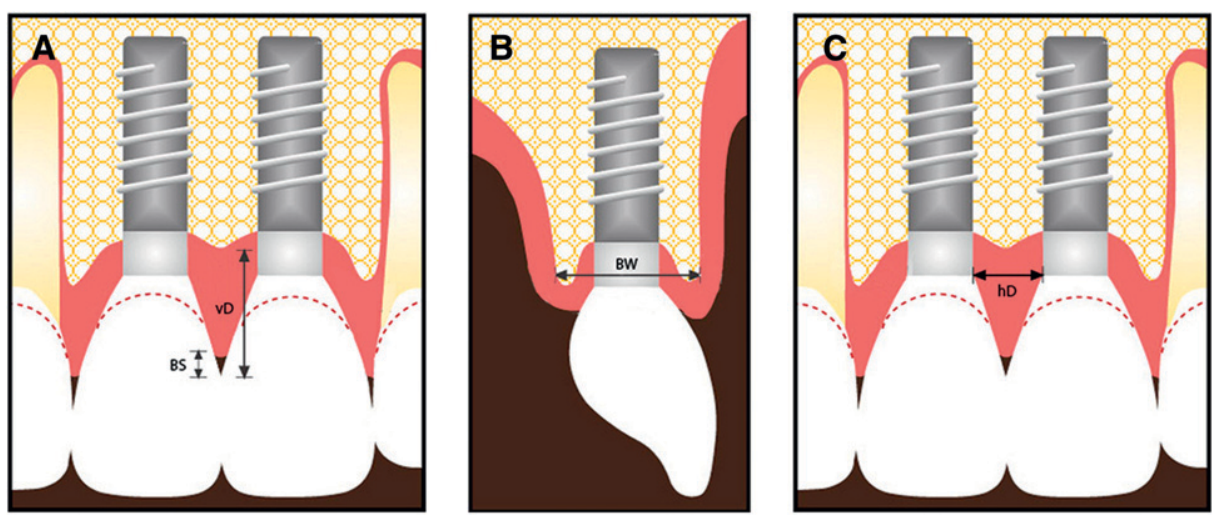

Figure $I$.

Schematic drawing showing the distance from the base of the interproximal contact to the alveolar crest (vertical distance $[\mathrm{VD}]$ ), distance from the base of the interproximal contact to the tip of the gingival papilla (A) alveolar bone width (B) and spacing between the implants $(\boldsymbol{C})$. BS= black space; BW= alveolar bone width; $H D=$ horizontal distance.

Fisher exact test, as appropriate. The significance level was set at $P \leq 0.05$.

\section{RESULTS}

\section{Effect of the Vertical Distance on the Presence of}

\section{Papilla and Black Space}

Interproximal papillae were always present (Jemt scores 2 and 3 ) when the mean vertical distance was $\leq 5 \mathrm{~mm}$ compared to when the distance was $>5 \mathrm{~mm}$ $(P=0.04)$. In addition, the black space was significantly greater when the mean vertical distance was $>5 \mathrm{~mm}$ at the total sites $(P=0.02$, Mann-Whitney $U$ test; correlation coefficient $=0.69, P=0.02$ ) (Table 1) and sites with interproximal papilla present $(P=0.02)$ (Table 1$)$. When the mean vertical distance was $<5 \mathrm{~mm}$, gingival papilla was always present, irrespective of the horizontal distance and bone width (Table 1).

\section{Effect of the Horizontal Distance Between Implants on the Presence of the Papilla and Black Space}

Papilla was frequently present when the mean horizontal distance was $\geq 4 \mathrm{~mm}$ compared to when the distance was $<4 \mathrm{~mm}(P=0.04)$, and a greater mean horizontal distance was observed when the papilla was present than when it was absent $(3.38 \pm 1.54$ versus $2.14 \pm 1.0 \mathrm{~mm} ; P=0.01)$. Black space was not associated with the mean horizontal distance $(P=$ 0.76 , Student $t$ test; correlation coefficient $=-0.03, P=$ 0.85) (Table 2).

\section{Effect of the Bone Width on the Incidence of the Papilla and Black Space}

Bone width was not associated with the presence of interproximal papilla $(P \geq 0.49)$ and black space $(P \geq 0.24$, Tukey or Mann-Whitney $U$ test; correlation coefficient $=0.02, P=0.92)($ Table 3$)$.
The interproximal papilla was present in $36.4 \%$ of cases in which the horizontal distance was $<3 \mathrm{~mm}$ and the bone width was $\geq 4 \mathrm{~mm}$, but it was never detected when the bone width was $<4 \mathrm{~mm}(P=0.13)$ (Table 4$)$.

\section{Effect of Soft-Tissue Biotype} on the Incidence of Papilla and Black Space

The mean soft-tissue thickness in areas of thick biotype was $3.10 \pm 0.61 \mathrm{~mm}$, and $1.93 \pm 0.35 \mathrm{~mm}$ in areas of thin biotype (Table 5).

The interproximal papilla was present in $40 \%$ of cases with thick biotype and in $22.22 \%$ of cases with thin biotype, but the difference was not statistically significant $(P=0.41)$ (Table 5). Soft-tissue biotype did not influence the black space $(P=0.41$, Student $t$ test; correlation coefficient $=0.25$, $P=0.19$ ) (Table 5).

\section{DISCUSSION}

In this study, the effects of buccal-palatal bone width on the incidence and height of the interproximal papilla between adjacent implants in esthetic areas of the mouth are assessed. The authors did not find an association between bone width or soft-tissue biotype and the presence or height of the papilla between adjacent implants in the esthetic areas, but the incidence and height of the interproximal papilla increased when the vertical and horizontal distances were $\leq 5$ and $\geq 4 \mathrm{~mm}$, respectively. In comparison, a vertical distance of $3 \mathrm{~mm}$ and mesio-distal distance of 3 to $4 \mathrm{~mm}$ were found associated with the presence of papilla in previous studies. ${ }^{3,4}$

Two main factors may explain the slight differences in the results between the present study and previous studies. ${ }^{2-5}$ First, only esthetic (anterior) areas were examined, whereas both anterior and posterior areas were considered in other studies between implants. ${ }^{2,4,5}$ Specifically, the anterior and posterior gingival interproximal papillae differ considerably and would yield different results. Second, different criteria were used to assess the presence and absence of the gingival papilla. The authors of the current study and Choquet et al. $^{3}$ considered the interproximal papilla to be present when it was categorized as score 2 or 3 using Jemt's classification, ${ }^{7}$ (i.e., gingival papilla filling more than half of the interproximal height), and Gastaldo et al. ${ }^{4}$ classified the gingival papilla as present when it filled any part of the interproximal space. 
Table I.

\section{Incidence of Interproximal Papilla and Size of Black Space According to the Vertical Distance}

\begin{tabular}{|c|c|c|c|c|c|c|}
\hline \multirow[b]{2}{*}{$\begin{array}{l}\text { Vertical } \\
\text { Distance (mm) }\end{array}$} & \multirow[b]{2}{*}{$n$} & \multirow[b]{2}{*}{$\begin{array}{l}\text { Black Space } \\
\text { (total, mm) }\end{array}$} & \multicolumn{2}{|c|}{ Present } & \multicolumn{2}{|c|}{ Absent } \\
\hline & & & $\begin{array}{c}\text { Interproximal } \\
\text { Papilla (\%) }\end{array}$ & Black Space (mm) & $\begin{array}{c}\text { Interproximal } \\
\text { Papilla (\%) }\end{array}$ & Black Space $(\mathrm{mm})$ \\
\hline$\leq 5$ & 5 & $0.5 \pm 0.50 *$ & $100^{\dagger}$ & $0.50 \pm 0.50$ & 0 & \\
\hline$>5$ & 24 & $2.04 \pm 1.46$ & 20.83 & $2.40 \pm 1.38$ & 79.17 & $1.95 \pm 1.49$ \\
\hline
\end{tabular}

Data are represented as mean \pm SD. $\mathrm{n}=$ number of examined areas.

* $P=0.02$ (Mann-Whitney $U$ test).

$\dagger P=0.04$ ( $\chi^{2}$ test $)$

Table 2.

\section{Incidence of Papilla and Size of Black Space According to the Horizontal Distance}

\begin{tabular}{|c|c|c|c|c|c|c|}
\hline $\begin{array}{l}\text { Horizontal } \\
\text { Distance (mm) }\end{array}$ & $n$ & $\begin{array}{l}\text { Black Space } \\
\text { (total, mm) }\end{array}$ & $\begin{array}{c}\text { Interproximal } \\
\text { Papilla (\%) }\end{array}$ & Black Space (mm) & $\begin{array}{c}\text { Interproximal } \\
\text { Papilla (\%) }\end{array}$ & Black Space (mm) \\
\hline$\leq 4$ & 23 & $1.86 \pm 1.56$ & $21.74 *$ & $1.60 \pm 1.78$ & 78.26 & $1.94 \pm 1.54$ \\
\hline$>4$ & 6 & $1.41 \pm 1.02$ & 83.33 & $1.30 \pm 1.09$ & 16.67 & $2.00 \pm 0.00$ \\
\hline
\end{tabular}

Data are represented as mean \pm SD. $\mathrm{n}=$ number of examined areas.

* $P=0.04$ ( $\chi^{2}$ test, incidence for 0 to $4 \times 4$ to $6 \mathrm{~mm}$ horizontal distance).

$\dagger P=0.01$ (Student $t$ test, papilla present $\times$ absent); $P=0.76$ (Student $t$ test, black space for $\leq 4 \times>4 \mathrm{~mm}$ horizontal distance).

Table 3.

Incidence of Interproximal Papilla and Size of Black Space According to Bone Width

\begin{tabular}{|c|c|c|c|c|c|c|}
\hline \multirow[b]{2}{*}{$\begin{array}{l}\text { Bone Width } \\
(\mathrm{mm})\end{array}$} & \multirow[b]{2}{*}{$n$} & \multirow[b]{2}{*}{$\begin{array}{l}\text { Black Space } \\
\text { (total, mm) }\end{array}$} & \multicolumn{2}{|c|}{ Present } & \multicolumn{2}{|c|}{ Absent } \\
\hline & & & $\begin{array}{c}\text { Interproximal } \\
\text { Papilla (\%) }\end{array}$ & Black Space (mm) & $\begin{array}{c}\text { Interproximal } \\
\text { Papilla (\%) }\end{array}$ & Black Space (mm) \\
\hline$\leq 2$ & 6 & $2.17 \pm 1.75$ & 33.33 & $0.50 \pm 0.71$ & 66.67 & $3.00 \pm 1.06$ \\
\hline$>2$ and $\leq 3$ & 4 & $0.75 \pm 0.65$ & 50.00 & $0.75 \pm 1.06$ & 50 & $0.75 \pm 0.35$ \\
\hline
\end{tabular}

Data are represented as mean \pm SD. $P \geq 0.24$ (Tukey or Mann-Whitney $U$ test, black space for $\leq 2 \times>2$ and $\leq 3 \times>3$ mm bone width); $P \geq 0.49$ (Fisher exact test, incidence for $\leq 2 \times>2$ and $\leq 3 \times>3 \mathrm{~mm}$ bone width). $\mathrm{n}=$ number of examined areas.

When implants are placed $<3.0$-mm apart, the risk of overlap bone resorption attributable to biologic width extension between the implants increases. This results in crestal bone loss between the implants, which severely affects the shape and volume of interproximal papilla. ${ }^{6,9}$ However, it has been suggested that a greater volume of alveolar bone on the buccal side of the interproximal area may compensate for the lack of interproximal bone caused by reduced interimplant distance, and the gingival papilla can thus be supported and maintained over a long period. ${ }^{10}$ In the present study, the interproximal papilla was present in $36.4 \%$ of cases in which the horizontal distance was $<3 \mathrm{~mm}$ and the bone width was $\geq 4 \mathrm{~mm}$, but it was never detected when the bone width was $<4 \mathrm{~mm}$. However, because of the small sample size, statistical significance could not be reached. In this study, powers of $100 \%, 85 \%$, and $\approx 8 \%$ are required for the vertical distance, horizontal distance, and bone width, respectively, to achieve a type I error rate $(\alpha)$ of 0.05 . To reach a power of $80 \%, 564$ areas would be required. Therefore, studies involving a larger number of participants are required.

It is important to note that the vertical and horizontal distances and bone width measured in this study are the results of the implant placement and 
Table 4.

Incidence of Interproximal Papilla When Horizontal Distance Between Implants Was $3 \mathrm{~mm}$ According to Bone Width

\begin{tabular}{lccc}
\hline & & \multicolumn{2}{c}{ Interproximal Papilla (\%) } \\
\cline { 3 - 4 } Bone Width $(\mathrm{mm})$ & $\mathrm{n}$ & Present & Absent \\
\hline$<4$ & 9 & 0 & 100 \\
24 & I & 36.36 & 63.64 \\
\hline
\end{tabular}

Data are represented as mean $\pm \mathrm{SD} ; P=0.49$ (Fisher exact test); $\mathrm{n}=$ number of examined areas.

Table 5.

Incidence of the Interproximal Papilla and Black Space Extension According to SoftTissue Biotype

\begin{tabular}{lcclc}
\hline & & & \multicolumn{2}{c}{$\begin{array}{c}\text { Interproximal } \\
\text { Papilla }(\%)\end{array}$} \\
\cline { 3 - 5 } Tissue Thickness $(\mathrm{mm})$ & $\mathrm{N}$ & Black Space $(\mathrm{mm})$ & Present & Absent \\
\hline Thin, $<2.5$ & 9 & $1.44 \pm 1.65$ & 22.22 & 77.78 \\
Thick, $\geq 2.5$ & 20 & $1.93 \pm 1.39$ & 40 & 60 \\
\hline
\end{tabular}

Data are represented as mean $\pm \mathrm{SD} ; P=0.42$ (Student $t$ test, black space for thin $\times$ thick), $P=0.41$ (Fisher exact test, incidence for thin $\times$ thick); $\mathrm{n}=$ number of examined areas.

prosthetic treatment. Therefore, implant placement and prosthetic treatment have an important impact on the future presence of interproximal papilla. The interproximal papilla has a major impact on the esthetic outcomes of implant therapy, which depend not only on the presence, but also on the height, form, symmetry, and color of gingival papillae. ${ }^{11}$ Some clinical and preclinical studies have demonstrated that the use of an implant-abutment interface with reduced diameter relative to the implant platform diameter (platform-switching concept) results in less crestal bone loss than which occurs with the use of implants with standard-diameter abutments. ${ }^{9,12}$ This issue is extremely important for the clinical placement of adjacent implants in esthetic areas and should be considered carefully, because the difference between the abutment diameter and the implant diameter may result in the placement of larger implants in relation to their abutments. This in turn could lead to decreased width of the buccal bone wall and create a blue effect as a result of transillumination of the implant through the thin bone and gingival tissue.

There are conflicting data regarding the effect of soft-tissue biotype on the presence of papilla. We did not find an association between soft-tissue biotype and the presence or extension of black space, which is substantiated by previous reports that have not found association between changes in soft-tissue margins and tissue biotype. ${ }^{13,14}$ In contrast, Romeo et al. ${ }^{15}$ showed that the presence of papilla was observed in $84 \%$ of individuals with thick biotype compared to $42.8 \%$ of individuals with thin biotypes.

Various methods for measuring the thickness of the mucosa have been used, including direct sounding using a periodontal probe, ${ }^{4,5}$ endodontic reamer, ${ }^{16}$ or injection needle. ${ }^{17}$ New methods using ultrasonic devices and computerized tomography ${ }^{18,19}$ are less invasive and can be considered alternative methods for the measurement of softtissue dimensions. However, there is no evidence showing their superior accuracy.

\section{CONCLUSIONS}

The findings of this study indicate that the gingival papilla is always present between adjacent implants in esthetic areas when the vertical distance is $\leq 5 \mathrm{~mm}$ and frequently present when the horizontal distance is $\geq 4 \mathrm{~mm}$, but the incidence and height of gingival papillae are not influenced by bone width or soft-tissue thickness. Furthermore, the gingival papilla is always present when the vertical distance is $\leq 5 \mathrm{~mm}$, independent of the horizontal distance or bone width. These findings may have important implications for esthetic results in patients receiving dental implants.

\section{ACKNOWLEDGMENTS}

The authors thank Ms. Marina Siqueira from Estudio Colirio, São Paulo, Brazil, for preparing the schematic drawing, Dr. Marta Riesco from Brazilian Association of Education Dentistry, São Paulo, Brazil, for assistance with the patient selection, and Professor Alfredo Gromatisk (in memoriam) for initial mentorship. The authors report no conflicts of interest related to this study.

\section{REFERENCES}

1. Buser D, Martin W, Belser UC. Optimizing esthetics for implant restorations in the anterior maxilla: Anatomic and surgical considerations. Int $J$ Oral Maxillofac Implants 2004;19(Suppl.):43-61.

2. Tarnow DP, Cho SC, Wallace SS. The effect of interimplant distance on the height of inter-implant bone crest. J Periodontol 2000;71:546-549.

3. Choquet V, Hermans M, Adriaenssens P, Daelemans P, Tarnow DP, Malevez C. Clinical and radiographic evaluation of the papilla level adjacent to single-tooth dental implants. A retrospective study in the maxillary anterior region. $J$ Periodontol 2001;72:1364-1371.

4. Gastaldo JF, Cury PR, Sendyk WR. Effect of the vertical and horizontal distances between adjacent implants and between a tooth and an implant on the incidence of interproximal papilla. J Periodontol2004;75:1242-1246. 
5. Tarnow D, Elian N, Fletcher P, et al. Vertical distance from the crest of bone to the height of the interproximal papilla between adjacent implants. J Periodontol 2003; 74:1785-1788.

6. Elian N, Jalbout ZN, Cho SC, Froum S, Tarnow DP. Realities and limitations in the management of the interdental papilla between implants: Three case reports. Pract Proced Aesthet Dent 2003;15:737-744, quiz 746.

7. Jemt $\mathrm{T}$. Regeneration of gingival papillae after singleimplant treatment. Int $J$ Periodontics Restorative Dent 1997; 17:326-333.

8. Linkevicius T, Apse P, Grybauskas S, Puisys A. The influence of soft tissue thickness on crestal bone changes around implants: A 1 -year prospective controlled clinical trial. Int J Oral Maxillofac Implants 2009; 24:712-719.

9. Elian N, Bloom M, Dard M, Cho S-C, Trushkowsky RD, Tarnow D. Effect of interimplant distance ( 2 and $3 \mathrm{~mm}$ ) on the height of interimplant bone crest: A histomorphometric evaluation. J Periodontol 2011;82;17491756.

10. Grunder U, Gracis S, Capelli M. Influence of the 3-D bone-to-implant relationship on esthetics. Int $J$ Periodontics Restorative Dent 2005;25:113-119.

11. Fürhauser R, Florescu D, Benesch T, Haas R, Mailath G, Watzek G. Evaluation of soft tissue around single-tooth implant crowns: The pink esthetic score. Clin Oral Implants Res 2005;16:639-644.

12. Lazzara RJ, Porter SS. Platform switching: a new concept in implant dentistry for controlling postrestorative crestal bone levels. Int J Periodontics Restorative Dent 2006;26:9-17.

13. van Kesteren CJ, Schoolfield J, West J, Oates T. A prospective randomized clinical study of changes in soft tissue position following immediate and delayed implant placement. Int J Oral Maxillofac Implants 2010; 25:562-570.

14. Chen ST, Darby IB, Reynolds EC. A prospective clinical study of non-submerged immediate implants: Clinical outcomes and esthetic results. Clin Oral Implants Res 2007; 18:552-562.

15. Romeo E, Lops D, Rossi A, Storelli S, Rozza R, Chiapasco $M$. Surgical and prosthetic management of interproximal region with single-implant restorations: 1 -year prospective study. J Periodontol 2008;79:1048-1055.

16. Ueno D, Sato J, Igarashi C, et al. Accuracy of oral mucosal thickness measurements using spiral computed tomography. J Periodontol 2011;82:829-836.

17. Olsson M, Lindhe J, Marinello CP. On the relationship between crown form and clinical features of the gingiva in adolescents. J Clin Periodontol 1993;20:570-577.

18. Müller HP, Schaller N, Eger T. Ultrasonic determination of thickness of masticatory mucosa: A methodologic study. Oral Surg Oral Med Oral Pathol Oral Radiol Endod 1999;88:248-253.

19. Januário AL, Barriviera M, Duarte WR. Soft tissue conebeam computed tomography: A novel method for the measurement of gingival tissue and the dimensions of the dentogingival unit. J Esthet Restor Dent 2008;20: 366-373, discussion 374.

Correspondence: Prof. Suzana Peres Pimentel, Rua Luís Goes, 2211 Mirandópolis, São Paulo, CEP 04043-200 Brazil. E-mail: suppimentel@yahoo.com.

Submitted October 29, 2011; accepted for publication March 6, 2012. 